\title{
Comparative study of the effects of different glucocorticosteroids on eosinophil survival primed by cultured epithelial cell supernatants obtained from nasal mucosa and nasal polyps
}

\author{
Joaquim Mullol, Antoni Xaubet, Eva López, Jordi Roca-Ferrer, Cèsar Picado
}

\begin{abstract}
Background - Supernatants from epithelial cell cultures enhance eosinophil survival in vitro, this effect being abrogated by previous incubation of eosinophils with glucocorticosteroids. This property has resulted in the development of an in vitro test to compare the potency of these drugs. A comparative study was performed with dexamethasone, methylprednisolone, deflazacort, and budesonide.
\end{abstract}

Methods - Human epithelial cell conditioned media (HECM) was generated from cultured epithelial cells obtained from healthy nasal mucosa and polyps. Eosinophils isolated from the peripheral blood were incubated with different corticosteroids for one hour before the addition of HECM. The inhibitory potency of the four steroids on the eosinophil survival index was compared using the concentration of steroid causing $50 \%$ inhibition $\left(\mathrm{IC}_{50}\right)$.

Results - Eosinophil survival was increased by HECM from both healthy nasal mucosa and polyps. All four steroids blocked HECM-induced eosinophil survival in a dose-dependent manner. On healthy nasal mucosa methylprednisolone was the least potent $\left(\mathrm{IC}_{50}=536 \mathrm{nM}\right)$, deflazacort $\left(\mathrm{IC}_{50}=264 \mathrm{nM}\right)$ was twice as potent as methylprednisolone, while budesonide and dexamethasone were approximately nine times as potent (both $\mathrm{IC}_{50}=58 \mathrm{nM}$ ). When potency was evaluated on the promoting effects of the HECM obtained from nasal polyps, the inhibitory potencies were lower and consequently the IC $_{50}$ values were higher when compared with HECM generated from healthy nasal mucosa: methylprednisolone $\left(\mathrm{IC}_{50}=\right.$ $546 \mathrm{nM})$, deflazacort $\left(\mathrm{IC}_{50}=390 \mathrm{nM}\right)$, dexamethasone $\left(\mathrm{IC}_{50}=76 \mathrm{nM}\right)$, and budesonide $\left(\mathrm{IC}_{50}=78 \mathrm{nM}\right)$.

Conclusions - The potencies of glucocorticosteroids can be compared by evaluating their effects on the survival of eosinophils previously primed by supernatants obtained from epithelial cell culture. The different effects of steroids on eosinophils primed by HECM obtained from healthy nasal mucosa compared with HECM obtained from nasal polyps suggest that polyps might represent more active tissue which is relatively resistant to treatment with corticosteroids.

(Thorax 1995;50:270-274)

Keywords: nasal mucosa, nasal polyps, eosinophil survival, glucocorticosteroids.

The presence of eosinophils and their products, together with the well established response of eosinophilic infiltration of the asthmatic airways to systemic and topical steroids, suggests that this inflammatory cell is of paramount importance in bronchial asthma. ${ }^{12}$

Based on the concept that the inflammatory process is the underlying factor responsible for disordered function of the airways in asthma, modern treatment favours the early use of drugs which modify inflammation of the airways. ${ }^{3}$ Treatment with steroids results in a considerable reduction in the number of eosinophils in the bronchial epithelium and submucosa, in parallel with an improvement in clinical symptoms and lung function indices of asthma. ${ }^{24}$

There is some evidence to suggest that structural cells such as epithelial cells may play a part in eosinophil infiltration by prolonging their survival in tissues. ${ }^{56}$ Supernatants from epithelial cell cultures enhance eosinophil survival in vitro, this effect being abrogated by previous incubation of eosinophils with steroids. ${ }^{56}$ This property has resulted in the development of an in vitro test to compare the anti-inflammatory potency of the different types of corticosteroids.

In this study we have investigated the effect of methylprednisolone, dexamethasone, deflazacort, and budesonide on eosinophil survival in vitro. Eosinophil survival was previously primed by adding supernatant of epithelial cell cultures obtained from both healthy nasal mucosa and nasal polyps.

\section{Methods \\ MATERIAL}

Ham's F-12 medium was provided by Biochrom KG (Berlin, Germany), Trypan blue, Hepes buffer, penicillin-streptomycin, donor fetal calf bovine serum, trypsin-EDTA, and RPMI 1640 medium were obtained from Flow Laboratories (Irvin, UK). Amphotericin B was provided by Squibb (Esplugues de Llobregat, Spain). Four steroids were used: dexa- 
methasone and methylprednisolone (MerckDarmstadt, Barcelona, Spain), deflazacort (Merrel Dow, Madrid, Spain), and budesonide (Astra-Ifesa, Barcelona, Spain). Hydrocortisone, human transferrin, bovine insulin, 3,3',5-triiode-L-tyrosine sodium salt, glutamine, $\mathrm{N}$-formyl-methionyl-leucyl-phenylalanine, protease type XIV, and glutaraldehyde were purchased from Sigma Co (St Louis, USA), while endothelial cell growth supplement and epidermal growth factor were acquired from Collaborative Research Inc (Bedford, USA). Percoll was supplied by Pharmacia LKB (Uppsala, Sweden) and Vitrogen 100 by Celtrix Laboratories (Palo Alto, USA).

\section{TISSUE HANDLING}

Healthy specimens of nasal mucosa were obtained during corrective surgery for nasal obstruction from patients with no clinical evidence of rhinitis and negative skin prick tests. Nasal polyps were obtained from patients with a positive or negative skin prick test undergoing nasal polypectomy. Nasal specimens were placed in Ham's F-12 medium supplemented with $100 \mathrm{IU} / \mathrm{ml}$ penicillin, $100 \mu \mathrm{g} /$ $\mathrm{ml}$ streptomycin, $2 \mu \mathrm{g} / \mathrm{ml}$ amphotericin $\mathrm{B}$, and immediately transported to the laboratory.

\section{EPITHELIAL CELL CULTURE}

Preparation of collagen coated culture plates Collagen coated culture dishes were prepared as previously described. ${ }^{6}$ The bottom of the wells from 24-well culture plates (Costar, Cambridge, USA) was covered with bovine dermal purified collagen (Vitrogen 100) and allowed to dry overnight. The collagen was then exposed to $0.5 \mathrm{ml}$ of $3.5 \% \mathrm{NH}_{4} \mathrm{OH}$ in distilled water for 25 minutes, washed with distilled water, exposed to $0.5 \mathrm{ml}$ of $2.5 \%$ glutaraldehyde in phosphate buffered saline (PBS) for 10 minutes, and washed twice again with distilled water. Ham's F-12 medium ( $2 \mathrm{ml}$ ) supplemented with antibiotics was then added to each well and the plates were placed in a $5 \%$ carbon dioxide incubator chamber at $37^{\circ} \mathrm{C}$ until used.

\section{Cell cultures}

Nasal epithelial cells from normal mucosa or polyps were isolated by protease digestion as previously reported. ${ }^{6}$ Tissue specimens were rinsed 2-3 times with Ham's F-12 medium supplemented with antibiotics and incubated in $0.1 \%$ protease type XIV in Ham's F-12 medium for 16 hours at $4^{\circ} \mathrm{C}$. After incubation $10 \%$ fetal bovine serum was added to neutralise protease activity and epithelial cells were detached by gentle agitation. Cell suspensions were filtered through a 60 mesh cell dissociation sieve (Sigma) and centrifuged at $500 \mathrm{~g}$ for 10 minutes at room temperature. The cell pellet was then resuspended in hormonally defined Ham's F-12 culture medium (Ham's HD) with the following reagents: $100 \mathrm{IU} / \mathrm{ml}$ penicillin, $100 \mu \mathrm{g} / \mathrm{ml}$ streptomycin, $2 \mu \mathrm{g} / \mathrm{ml}$ amphotericin B, $150 \mu \mathrm{g} / \mathrm{ml}$ glutamine, $5 \mu \mathrm{g} / \mathrm{ml}$ transferrin,
$5 \mu \mathrm{g} / \mathrm{ml}$ insulin, $25 \mathrm{ng} / \mathrm{ml}$ epidermal growth factor, $15 \mu \mathrm{g} / \mathrm{ml}$ endothelial cell growth factor supplement, $200 \mathrm{pM}$ triiodothyronine, and $100 \mathrm{nM}$ hydrocortisone. Cell suspensions $\left(10^{5}\right.$ cells/well) were plated on collagen coated wells in $2 \mathrm{ml} \mathrm{Ham}$ 's HD medium and cultured in a $5 \%$ carbon dioxide humidified atmosphere at $37^{\circ} \mathrm{C}$. The culture medium was changed at day 1 and every two days thereafter. Monolayer cell confluence was achieved after 6-10 days of culture.

GENERATION OF HUMAN EPITHELIAL CONDITIONED MEDIA (HECM)

When epithelial cell cultures reached confluence Ham's HD medium was switched to RPMI-1640 medium supplemented with $10 \%$ fetal bovine serum, $100 \mathrm{IU} / \mathrm{ml}$ penicillin, $100 \mu \mathrm{g} / \mathrm{ml}$ streptomycin, $2 \mu \mathrm{g} / \mathrm{ml}$ amphotericin $\mathrm{B}, 150 \mu \mathrm{g} / \mathrm{ml}$ glutamine, and $25 \mathrm{nM}$ Hepes buffer (RPMI 10\%). Human epithelial cell conditioned medium (HECM) was generated after 48 hours of incubation with RPMI $10 \%$, harvested from cultures, centrifuged at $400 \mathrm{~g}$ for 10 minutes at room temperature, sterilised through $0.22 \mu \mathrm{m}$ filters (Millipore), and stored at $-70^{\circ} \mathrm{C}$ until used.

EOSINOPHIL ISOLATION

Peripheral blood eosinophils were obtained from atopic and non-atopic subjects with more than 3\% eosinophils in peripheral blood using a method previously described. ${ }^{6}$ Percoll solution with a density of $1130 \mathrm{~g} / \mathrm{ml}$ was diluted with $10 \times$ PBS to obtain an osmolarity of 310-320 $\mathrm{mOsm} / \mathrm{kg}$ and diluted with $1 \mathrm{~N}$ PBS to obtain concentrations of $65 \%$ and $75 \%$. Fifteen $\mathrm{ml}$ of the $65 \%$ Percoll solution was placed in $50 \mathrm{ml}$ conical tubes and $15 \mathrm{ml}$ of the $75 \%$ Percoll solution was layered below by means of a narrow catheter placed at the bottom of the tube. Whole blood $(100 \mathrm{ml})$ anticoagulated with $0.3 \%$ EDTA was incubated with $1 \mu \mathrm{M} \mathrm{N}$-formyl-methionyl-leucyl-phenylalanine in a shaking water bath at $37^{\circ} \mathrm{C}$ for 20 minutes; $15 \mathrm{ml}$ blood was then layered above the Percoll gradients and centrifuged at $400 \mathrm{~g}$ for 25 minutes at room temperature. Plasma and mononuclear/neutrophil bands located above the Percoll gradients were aspirated and discarded; $10 \mathrm{ml}$ of the eosinophil band, located between the $65 \%$ and $75 \%$ Percoll layers, were collected and mixed with RPMI $10 \%$ and centrifuged at $400 \mathrm{~g}$ for 10 minutes at room temperature. Contaminant erythrocytes were removed by cold hypotonic lysis. The cell suspension was washed and resuspended in RPMI $10 \%$. Cell viability ( $>95 \%$ ) was assessed by Trypan blue dye exclusion and the percentage of eosinophils obtained ( $>90 \%$ ) was quantified by cytocentrifuge smears stained with MayGrünwald-Giemsa.

\section{EOSINOPHIL CULTURES}

The effect on eosinophil survival of HECM, generated from both healthy nasal mucosa and nasal polyps, was measured. Eosinophils at 
a concentration of approximately $250000 / \mathrm{ml}$ were incubated in six well tissue cultures (Sterling Ltd, Feltham, UK) with or without (negative control) HECM and the survival index was assessed at day 4 . The HECM concentrations used were $10 \%$ for nasal polyps and $25 \%$ for healthy nasal mucosa. These concentrations were selected because they were found previously to be equipotent with regard to eosinophil survival priming effect. ${ }^{6}$ The effect of steroids on HECM-induced eosinophil survival was tested by incubating systemic and inhaled steroids (from $100 \mathrm{pM}$ to $10 \mu \mathrm{M}$ ) with eosinophil suspensions at $37^{\circ} \mathrm{C}$ over one hour before the addition of HECM. Dexamethasone and methylprednisolone were diluted in RPMI while deflazacort and budesonide were diluted in dimethyl sulphoxide. The final concentration of dimethyl sulphoxide $(0.01 \%)$ used in the steroid experiments had no effect on eosinophil survival.

EOSINOPHIL SURVIVAL INDEX

The eosinophil survival index was calculated as follows: (number of eosinophils recovered)
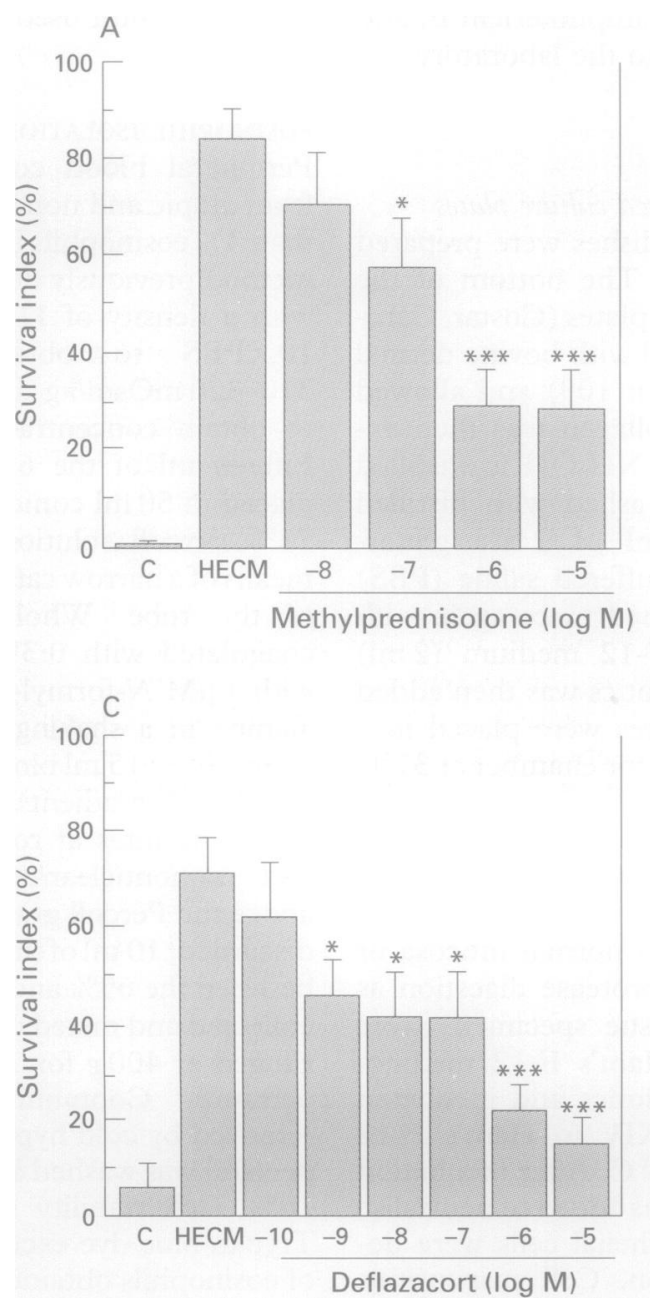

$\times$ (percentage of eosinophil viability)/(number of eosinophils delivered on day 0 ).

\section{DATA ANALYSIS}

The statistical evaluation was performed on a microcomputer MacIntosh SE/30 (Apple Computer, Cupertino, California, USA) using the statistical software package Statview 512+ (Brainpower Inc, Calabasas, California, USA). All results are expressed as mean (SE). The Student's $t$ test for unpaired sample analysis was used for statistical comparisons, $p<0.05$ being considered statistically significant.

\section{Results}

EFFECTS OF GLUCOCORTICOSTEROIDS ON EOSINOPHIL SURVIVAL

Human epithelial cell conditioned media (HECM) at a concentration of $25 \%$ from healthy nasal mucosa (figure) and $10 \%$ from nasal polyps (table 1) significantly increased the eosinophil survival with respect to controls $(p<0 \cdot 0001)$. No differences were found in the effect on eosinophil survival between HECM
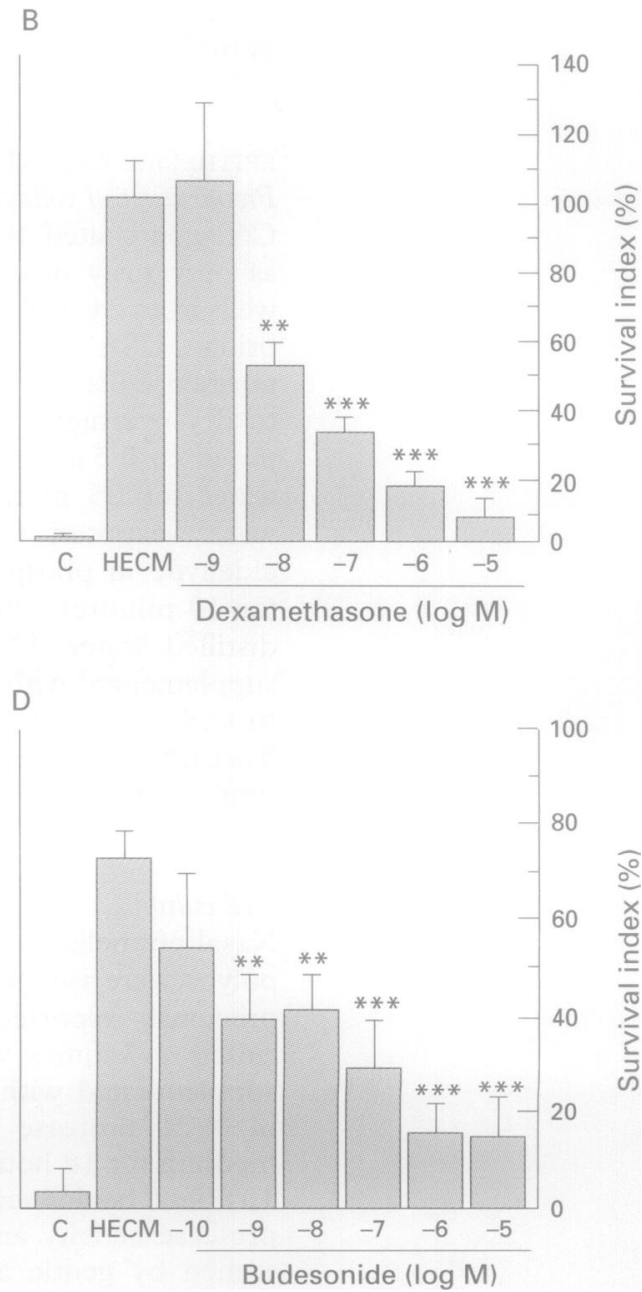

Effect of $(A)$ methylprednisolone, $(B)$ dexamethasone, $(C)$ deflazacort, and (D) budesonide on eosinophil survival induced by human epithelial cell conditioned media (HECM) from healthy nasal mucosa. C=eosinophil survival at day 4 when incubated with culture media alone (negative control), HECM=eosinophil survival at day 4 after stimulation with epithelial cell secretions (positive control). Preincubation of eosinophils with methylprednisolone (from $10^{-8}$ to $10^{-5} \mathrm{M}, n=8$ ), dexamethasone (from $10^{-9}$ to $10^{-5} \mathrm{M}, n=5$ ), deflazacort (from $10^{-10}$ to $10^{-5} \mathrm{M}, n=8$ ), and $\left.10^{-5} \mathrm{M}, n=8\right)$, dexamethasone (from $10^{-9}$ to $\left.10^{-5} \mathrm{M}, n=5\right)$, deflazacort (from $10^{-1}$ to $\left.10^{-5} \mathrm{M}, n=8\right)$, and
budesonide (from $10^{-10}$ to $10^{-5} \mathrm{M}, n=5$ ) inhibited the eosinophil survival induced by HECM in a dose-dependent manner. The minimal and significant inhibitory concentration was $10^{-9} \mathrm{M}$ for budesonide and deflazacort, $10^{-8} \mathrm{M}$ for dexamethasone, and $10^{-7} M$ for methylprednisolone. Values are expressed as mean (SE) survival index (\%). ${ }^{*} p<0 \cdot 05$, ${ }^{* *} p<0 \cdot 01,{ }^{* * *} p<0.001$ versus HECM value (unpaired Student's $t$ test). 
Table 1 Effect of glucocorticosteroids on eosinophil survival induced by human epithelial cell conditioned media (HECM) from nasal polyps expressed as mean (SE) survival index (\%)

\begin{tabular}{|c|c|c|c|c|}
\hline & $\begin{array}{l}\text { Methylprednisolone } \\
(n=5)\end{array}$ & $\begin{array}{l}\text { Deflazacort } \\
(n=5)\end{array}$ & $\begin{array}{l}\text { Dexamethasone } \\
(n=5)\end{array}$ & $\begin{array}{l}\text { Budesonide } \\
(n=6)\end{array}$ \\
\hline $\begin{array}{l}\text { Control } \\
\text { HECM }\end{array}$ & $\begin{array}{r}1.0(0 \cdot 3) \\
85 \cdot 6(6 \cdot 8)\end{array}$ & $\begin{array}{r}2 \cdot 0(1 \cdot 7) \\
81 \cdot 3(5 \cdot 5)\end{array}$ & $\begin{array}{r}3 \cdot 5(1 \cdot 6) \\
84 \cdot 1(4 \cdot 3)\end{array}$ & $\begin{array}{r}0 \cdot 7(0 \cdot 2) \\
79 \cdot 2(8 \cdot 0)\end{array}$ \\
\hline $\begin{array}{c}\text { HECM aft } \\
10^{-8} \mathrm{M} \\
10^{-7} \mathrm{M} \\
10^{-6} \mathrm{M} \\
10^{-5} \mathrm{M}\end{array}$ & $\begin{array}{l}\text { acubation: } \\
69 \cdot 5(9 \cdot 7) \\
52 \cdot 8(7 \cdot 2)^{* *} \\
34 \cdot 3(6 \cdot 5) * * * \\
27 \cdot 8(5 \cdot 7)^{* * *}\end{array}$ & $\begin{array}{l}80 \cdot 3(13 \cdot 0) \\
51 \cdot 9(13 \cdot 2) \\
21 \cdot 8(8 \cdot 4)^{* * *} \\
15 \cdot 0(4 \cdot 7)^{* * *}\end{array}$ & $\begin{array}{r}74 \cdot 1(12 \cdot 9) \\
32 \cdot 6(8 \cdot 7)^{* * *} \\
26 \cdot 6(9 \cdot 0)^{* * *} \\
8 \cdot 1(3 \cdot 8)^{* * *}\end{array}$ & $\begin{array}{l}58 \cdot 3(7 \cdot 5) \\
34 \cdot 5(8 \cdot 3)^{* *} \\
24 \cdot 4(8 \cdot 9)^{* * *} \\
16 \cdot 1(10)^{* * *}\end{array}$ \\
\hline
\end{tabular}

Control = spontaneous eosinophil survival at day 4 (negative control); HECM=eosinophil survival after stimulation with epithelial

${ }^{* *} \mathrm{p}<0.01,{ }^{* * *} \mathrm{p}<0.001 v$ HECM value (unpaired $t$ test).

generated from healthy nasal mucosa $(25 \%$ concentration) and HECM generated from nasal polyps ( $10 \%$ concentration). These findings confirm a previous study which showed that both concentrations show a similar capacity to increase eosinophil survival. ${ }^{6}$ Furthermore, the preincubation of eosinophils with the four steroids decreased the survival index in a dose-dependent manner in experiments using HECM from both healthy nasal mucosa (figure) and nasal polyps (table 1).

In the experiments using HECM from healthy nasal mucosa the lowest effective steroid concentration was $10^{-9} \mathrm{M}$ for budesonide and deflazacort, $10^{-8} \mathrm{M}$ for dexamethasone, and $10^{-7} \mathrm{M}$ for methylprednisolone (figure). When using HECM from nasal polyps the lowest effective steroid concentration was $10^{-7} \mathrm{M}$ for budesonide, dexamethasone, and methylprednisolone, and $10^{-6} \mathrm{M}$ for deflazacort (table 1).

COMPARISON OF INHIBITORY POTENCY OF STEROIDS ON EOSINOPHIL SURVIVAL

The inhibitory potency of the four steroids on the eosinophil survival index was compared by using the $\mathrm{IC}_{50}$ value (table 2 ). The $\mathrm{IC}_{50}$ represents the concentration of the drug at which $50 \%$ of inhibition is produced. Budesonide and dexamethasone showed a similar potency and proved to be the most active, followed by deflazacort and methylprednisolone. With the exception of methylprednisolone, the effects of these steroids were lower on eosinophil survival promoted by HECM from nasal polyps than from healthy nasal mucosa.

A scale of the relative inhibitory potency of these steroids was made by giving a value of 1 to the inhibitory effect of the least potent steroid (methylprednisolone) (table 2). Deflazacort was approximately twice as potent as methylprednisolone while budesonide and dexamethasone were nine (nasal mucosa) and seven (nasal polyps) times as potent.

Table 2 Comparison of the effect of glucocorticoids on preventing eosinophil survival induced by epithelial cells

\begin{tabular}{|c|c|c|c|c|}
\hline & \multicolumn{2}{|c|}{ Nasal mucosa } & \multicolumn{2}{|l|}{ Nasal polyp } \\
\hline & $I C_{50}(n M)$ & Potency & $I C_{s o}(n M)$ & Potency \\
\hline $\begin{array}{l}\text { Methylprednisolone } \\
\text { Deflazacort } \\
\text { Budesonide } \\
\text { Dexamethasone }\end{array}$ & $\begin{array}{r}536 \\
264 \\
58 \\
58\end{array}$ & $\begin{array}{l}1 \\
2 \cdot 1 \\
9 \cdot 4 \\
9 \cdot 4\end{array}$ & $\begin{array}{r}546 \\
390 \\
78 \\
76\end{array}$ & $\begin{array}{l}1 \\
1 \cdot 4 \\
7 \cdot 0 \\
7 \cdot 2\end{array}$ \\
\hline
\end{tabular}

$\mathrm{IC}_{50}=$ steroid concentration that inhibits $50 \%$ of eosinophil-induced survival.

\section{Discussion}

Rhinitis and bronchial asthma, either allergic or non-allergic, are characterised by a chronic inflammation of the respiratory tract in which the accumulation of eosinophils in the tissue is a characteristic feature. ${ }^{1}$ Tissue eosinophilia is probably regulated by a complex process in which different cells, including epithelial cells, are involved. Previous in vitro studies have shown that glucocorticosteroids may modulate tissue eosinophilia by decreasing eosinophil survival promoted by epithelial cell supernatants. ${ }^{56}$ Because this in vitro model is a representation of the close relation that exists between epithelial cells and eosinophils in vivo, we determined whether this method may be useful in the assessment of the potency of different corticosteroids.

Our results confirm previous studies showing the impaired ability of supernatants to prolong eosinophil survival when steroids are added to a culture of eosinophils primed with epithelial cell supernatants. ${ }^{56}$ Our method proved to be able to detect differences among steroids.

According to previous studies the antiinflammatory activity of dexamethasone is five times more potent than that of methylprednisolone. ${ }^{7}$ In our study we found the inhibitory effect of dexamethasone on eosinophil survival to be 7-9 times stronger than the effect exerted by methylprednisolone.

The potency of steroids has been compared by evaluating their effect on IgE mediated histamine release from basophils. ${ }^{8}$ With this in vitro model budesonide proved to be more potent than dexamethasone. These results contrast with our study which showed that both steroids exert similar inhibitory effects on eosinophil survival promoted by epithelial cell supernatants.

Investigation of new glucocorticosteroid molecules is usually carried out using animal models such as the cotton pellet model and acute ear inflammation. ${ }^{.10}$ The skin vasoconstrictor model of Place has also been extensively used to assess the anti-inflammatory potency of steroids. ${ }^{11}$ Although these and other models are useful in comparing the potency of different steroids, the inflammatory process involved in these experimental studies differs with respect to the airway inflammatory reaction present in bronchial asthma. The lack of eosinophilic infiltration in these animal models is the most striking difference. These differences might explain, at least in part, discrepancies between experimental studies with animals and clinical 
trials. For instance, using the ear oedema model in mice the potency of inhibition of inflammation for budesonide with respect to beclomethasone was 1 to $0 \cdot 4 .^{9}$ Clinical trials, however, have failed to demonstrate clear differences between these inhaled steroids in the clinical control of asthma. ${ }^{1213}$

Epithelial cells have the potential to participate actively in the inflammatory process that affects the airways in rhinitis and bronchial asthma. Because of their abundance and strategic position, epithelial cells are probably the main target for topically applied steroids. Our in vitro model might represent better than animal models the events that occur in the airways of patients with rhinitis and asthma when treated with topical steroids.

The new glucocorticosteroid deflazacort, an oxazoline derivative of prednisolone, has recently been introduced in Europe. ${ }^{1415}$ It seems that the therapeutic properties of deflazacort are similar to other widely used steroids but its side effect profile is less severe. Deflazacort in equipotent doses to other steroids is less diabetogenic and osteopenic. ${ }^{14-16}$ The therapeutic dosage of deflazacort equivalent to prednisone has been assessed in rheumatoid arthritis and polymyalgia rheumatica where deflazacort appeared to be clinically equivalent when the drug was administered in a ratio of $6 \mathrm{mg}$ deflazacort to $5 \mathrm{mg}$ prednisone. ${ }^{17}$

The effect of glucocorticosteroids on eosinophil survival was generally less marked on HECM obtained from nasal polyps than on HECM generated from healthy nasal mucosa. The reason for this finding is unclear. As eosinophil infiltration is a usual finding in nasal polyposis, the different effect of steroids on epithelial cells, depending on their origin, suggests that nasal polyps represent a more active tissue which might be more resistant to antiinflammatory drugs, perhaps by producing more cytokines involved in eosinophil recruitment and activation. ${ }^{56}$ Because these patients are usually treated with regular or intermittent systemic and topical steroids, the possible role of this therapy on the in vitro resistance of epithelial cells to steroids should not be overlooked.

We have shown that the potency of systemic and topical steroids can be evaluated using eosinophils previously primed by supernatants obtained from epithelial cell cultures. The different effects of steroids on eosinophils primed by HECM obtained from healthy nasal mucosa compared with HECM obtained from nasal polyps suggest that polyps might represent a more active tissue, relatively resistant to treatment with steroids.

This study was supported by grants from Dirección General de Investigación Científica y Técnica (DGICYT 91/0041 and PM 92/732), Sociedad Española de Neumología y Cirugía Torácica (SEPAR-Merrel Dow/91), and Astra Laboratories. Dr Mullo was supported by orants from Dirección General de Inde Pneumologia. Eva López and Jordi Roca-Ferrer were supported by

1 Djukanovic R, Roche WR, Wilson JW, Beasley CRW, Twentyman OP, Howarth PH, et al. Mucosal inflammation in asthma. State of the art. Am Rev Respir Dis 1990;142: 434-57.

2 Djukanovic R, Wilson JW, Britten KM, Roche WR, Howarth PH, Holgate ST. The effects of inhaled beclomethasone dipropionate (BDP) on inflammatory cells in the asthmatic airway. $₹$ Alleryy Clin Immunol 1991;87:172-7.

3 British Thoracic Society. Guidelines for management of asthma in adults: I. Chronic persistent asthma. BMf 1990 ; asthma in adul

4 Scheleimer RP. Effects of glucocorticosteroids on in flammatory cells relevant to their therapeutic applications. Am Rev Respir Dis 1990;141(Suppl):59-69.

5 Cox G, Ohtoshi T, Vancheri C, Denburg JA, Dolovich J, Gauldie J, et al. Promotion of eosinophil survival by human bronchial epithelial cells and its modulation by steroids. Am $\mathcal{F}$ Respir Cell Mol Biol 1991;4:525-31.

6 Xaubet A, Mullol J, López E, Roca-Ferrer J, Rozman M, Carrion T, et al. Comparison of the role of nasal polyps and normal nasal mucosa epithelial cells on in vitro eosinophil survival. Mediation by GM-CSF and inhibition by dexasurvival. Mediation by GM-CSF and inhibition

7 Haynes RC. Adrenocorticotropic hormone; adrenocortica steroids and their synthetic analogs; inhibitors of the synthesis and actions of adrenocortical hormones. In: Goodman Gilman A, Wall TW, Nies AS, Taylor P, eds. The pharmacological basis of therapeutics. New York: Pergamon Press, 1990:1431-62.

8 Bergstrand H, Björnson A, Lundquist B, Nilsson A, Brattsand $R$. Inhibitory effect of glucocorticoids on anti-IgEinduced histamine release from human basophilic leukocytes: evidence for a dual mechanism of action. Allergy kocytes: evidence

9 Brattsand R, Andersson PT, Edsbacker S, Ryrfeldt A. Development of glucocorticoids with lung selectivity. In Ellul-Micaleff R, Lam WK, Toogood JH, eds. Advances in the use of inhaled corticosteroids. Amsterdam: Excerpta Medica, 1987:60-78.

10 Kalstrom L, Brattsand R, Lvgren U, Svensjo E, Roempke $K$. A rat model for testing anti-inflammatory action in I. A rat the effect of glucocorticoids in this model. In: Ellul-Micaleff R, Lam WK, Toogood JH, eds. Advances in the use of inhaled corticostemids. Amsterdam: Excerpta in the use of inhaled cort

1 Place VA. Precise evaluation of topically applied corticosteroid potency. Arch Dermatol 1970;101:531-7.

12 Banan D. A comparison of inhaled budesonide and beclomethasone dipropionate in childhood asthma. $B r \mathcal{F} D i$ Chest 1987;81:170-5.

13 Springer C, Avital A, Maayan Ch, Rosler A, Godfrey S. Comparison of budesonide and beclomethasone dipropionate for treatment of asthma. Arch Dis Child 1987; 62:815-9.

14 Gennari C, Imbimbo B, Montagnani M, Bernini M, Nardi $\mathrm{P}$, Avioli LV. Effect of prednisone and deflazacort on mineral metabolism and parathyroid hormone activity in humans. Calcif Tissue Int 1984;36:245-52.

15 Gennari C, Imbimbo B. Effects of prednisone and deflazacort on vertebral bone mass. Calcif Tissue Int 1985 37:592-3.

16 Bruno A, Cavallo-Perin P, Cassader M, Pagano G. Deflazacort vs prednisone: effects on blood glucose control in insulin-treated diabetics. Arch Intern Med 1987:147: 679-80.

17 Avioli LV. Potency ratio. A brief synopsis. $\mathrm{Br} \mathcal{F}$ Rheumatol 1993;32(Suppl 2):24-6. 